\title{
Wellbeing: Through the Lens of Indian Traditional Conceptualisations
}

\author{
Venkat Pulla $^{1, *}$, Salagame K. K. K. ${ }^{2}$ \\ ${ }^{1}$ Adjunct Senior Research Fellow, Institute of Land, Water and Society, ILWS, Charles Sturt University, Wagga Wagga, NSW, Australia \\ ${ }^{2}$ Formerly Professor of Psychology, University of Mysore, Mysuru, India
}

'The happiest people in the world do not live in the best circumstances, yet their joy is daily choice'

- Author unknown

\begin{abstract}
Well-being is a multifaceted construct that endeavours to provide an explanation to the length and breadth of human experience. Research on well-being currently focusses on a couple of perspectives: the hedonic approach, which focuses primarily on happiness and defines well-being regarding fulfilment of pleasure and escaping or avoiding pain, and the eudaimonic approach, which emphasises on finding meaning and Self-realization in the Indian context is Atma sakshatkara which is different from actualizing potentials. The objectives of this paper are three-fold. To explore how people, perceive optimism, hope, and resilience. To explore the meanings of the traditional Indian concepts of ananda, sukha and dukha, and to relate this to the process of meaning making in cancer patients in the west. How have they found acceptance to face their daunting odds and in turn how did they explore hope? Surely hope makes survivor's lives (and the lives of those around them) more liveable.
\end{abstract}

Keywords Happiness, Contentment, Hope and Resilience, Social Work, Well-being in the Indian Tradition

\section{Introduction}

At the outset the authors propose that the notions of happiness and wellbeing as being intrinsically connected with spirituality. Living in the western world for over two decades, far away from India the land of his birth, the first author has been intrigued with the concepts of being and wellbeing. His observations are that:

The mainstream culture in the west does not seem to place happiness and wellbeing in a spiritual framework, and that even helping professionals such as social workers, counsellors seem to remain aloof and cold to this vital and pervasive dimension of spirituality (Pulla, 2014). This despite, our recognition that one's spiritual side provides the required impetus for coping and human resilience (Pulla, 2014). We begin this paper with the following assertions:

- That when ordinary people raise questions and seek answers to the meaning, purpose, and connectedness of life, they intrinsically hitch their wagon to wellbeing.

- When people augment their strengths and resources and work towards overcoming personal obstacles and environmental blocks, they hike their path to resilience and

- When they learn to take steps to look within, think ontologically, and move through their crisises with equanimity - they are on their pathway to discover hope and finally,

- $\quad$ That surviving leads to resilience and it is the pride in survival that builds the strength to help overcome additional obstacles.

\section{Optimism, Resilience, and Hope}

As said above the process of surviving that leads to resilience in turn generates optimism and hope. Hope for many may be an impossible dream, but for those who are resilient, it is the only possible step to take to continue a purposeful life. We will address concepts such as optimism, resilience and hope on the one hand and concepts related to pleasure, happiness, and wellbeing on the other.

We intend to view these terms that spell different aspects of wellbeing from a lay perspective. To illustrate this we present the story of Kay Benjamin and her journey through cancer. In March 2006 Kay was diagnosed with breast 
cancer. During her regular visits for chemotherapy, she spotted a poster advertising "Oncology on Canvas" a worldwide bi-annual art competition. It stuck in her mind. It possibly was and is a fantastic project and very therapeutic. Although it stuck in her mind, she didn't pursue it. Kay's three children and husband sought to give her something to inspire and help her. Her daughter's fiancé suggested an easel. Having studied fine arts in her late teens, Kay hadn't seriously focused on the artistic gift she had for most of her adult life. During chemotherapy, she started to draw again. Further, into the treatment, she found that she couldn't focus. Her gift stood unused for some time. Finally, when the fog lifted, Kay began to draw her family. She focused on her gift and the pleasure of the talent she was born with but had thrown to one side for most of her life.

I started exercising, and I started to draw and sew again. I haven't looked back since. It was then I decided I needed a goal. Five months later I packaged up my artwork for Oncology on Canvas with the 250, word anonymous essay that had to accompany it and sent it off to New York. It was judged a few months later, and the winners were announced in New York City. I didn't win my category, but I did make the selection to have my work go on tour for the next two years. I was ecstatic! (Benjamin, 2014).

Kay Benjamin (2014) further wrote:

Thus, my entry is called the gift. The gift of life........the gift of love...........and the gift I was born with. My collage of drawings and photos formed a mosaic. It is my journey through breast cancer, loss of a breast, radiation burn, excess weight, hair loss and loss of self-esteem. The focal point is my gift..........the easel. The resolve to fight cancer and allow it to be an inspiration rather than a burden is what still drives me daily. I don't focus on it; I cherish it. This piece was the coming to terms with my body image again. Being proud to finally assess myself nude and hopefully show others that the loss of a breast is not ugly after all.

Clearly, there is a lesson of optimism and hope in Kay Benjamin's story, indicated in the passage of coping and resilience and endurance of the trauma. Certainly, the concept of resilience has changed from a negative approach of the absence of psychopathology to a positive focus on competence and adaptive behaviour. People seem to have a relatively good psychological outcome despite suffering. It is not immunity or imperviousness to trauma but rather the ability to recover from adverse experiences that define resilience (Rutter, 2007). But, of course, it is not just resistance to adversity but rather the ability to grow and develop under difficult conditions that can further resilience into hope. We will now present another narrative of Shelly's (2014) narrative from New South Wales, Australia to illustrate this further. She writes:

My early stage breast cancer was diagnosed in 2008 when I was 50. Shortly afterwards I had a lumpectomy followed by radiotherapy and am now on hormone therapy. With tremendous support from my husband, a dedicated medical team and a huge dose of positive thinking, I believe I've travelled the first year of my journey relatively unscathed. Six months after surgery we attended an open day at the Sydney Trapeze School so our seven year -old son could try out the flying trapeze. I was offered a turn and, albeit a little hesitantly due to surgery scars and healing tissue, I agreed. The adrenalin soared through my body as I swung eight meters above the ground. Terrified, I tumbled into the safety net and onto wobbly legs, swearing it was the scariest experience of my life. Just 30 minutes later, once my feet were back on terra firma, and the adrenalin rush had ended, my feelings changed. I loved it. For my birthday two days later, my husband surprised me with a voucher for three 2hour, trapeze classes. What a gift. Mentally, I was up for it; however, it was several months before I felt physically ready for this strenuous challenge. Around a year after my breast cancer diagnosis, I completed my three classes. I can now successfully perform a knee hang, exit with a back flip into the net and execute a mid-air catch with the instructor. I'll never know whether it was the experience of surviving breast cancer that allowed me the courage to fly on the trapeze, but I do know it is so far the most exhilarating experience of my life. Whilst I won't be running away to join a circus anytime soon, I will continue flying the trapeze as I continue my journey.

We further illustrate this with another example of a young kid that thrives amidst adversities and seeks to fulfill his desires and ambitions as he movesw on into his teens and adulthood. This illustration is from a Oscar winning movie called Slum Dog Millionaire produced by Danny Boyle (2008). It was a vivid commentary on the poverty, make shift tin and tarpaulin housing and living of almost one fifth of Mumbai population. Amidst the images of impoverishment there is an immensely resilient and loving boy from the garbage-ridden slums whose name is Jamal. His adventures take him from the desolate poverty of begging on the streets to the wildly popular Television series game show stage of "Who Wants to be a Millionaire?" For those who have never seen this movie, and for those who have seen it, a brief refresher narrative is not out of place. Jamal, the central figure in the movie, was 
introduced at seven years old as a 'Slumdog,' born in Mumbai and living with his Muslim mother and his older brother, Salim, a born hustler. They possessed a lot of energy and played in the garbage around the slums in which they lived. A high point in Jamal's early life is when he manages to get the signature of one of India's Bollywood's screen stars Mr. Amitabh Bachchan and the means whereby he accomplishes this feat is a sign of his creativity and resilience. A low point in Jamal's early life is when his mother is brutally killed, and anti-Muslim rioters overran their slum. Jamal and Salim find themselves on the streets without any resources or hope.

How difficult is it to surmise these three case histories (two real and one fictional) there is only ability to recover from adversity? And if we let Kay Benjamin, Shelly and Jamal come into our hearts can they not teach us a lot about survival? Watching the results of their 'awareness,' even better if I used the word 'consciousness,' we are challenged to take note of the many teachable moments in our lives. Time and time again, Jamal is tested, and in the process, he develops his variable strengths, resilience, and self-directedness to fix his sights and make his moves (Frederic \& Brussat, 2008).

The concept of resilience has now become positive for everyone and has become a substance devoid of psychopathology that leads to a positive focus on competence and adaptive behaviours so that human beings can enjoy life. Great outcomes, despite suffering risk experiences, are all that people want. Resilience is not imperviousness to trauma but rather the ability to recover from adverse experiences - this is what one should celebrate. One additional learning seems to be that even the most impervious will collapse if there is conscious determination.

\section{Pleasure, Happiness, and Well-being}

In the last, few decades there have been many studies on pleasure, happiness and wellbeing broadly discussed under two different headings hedonia and eudaimonia (Ryan \& Deci, 2001). Diener (1984), for instance, coined a term called "subjective wellbeing" (SWB). He proposed that people would evaluate for themselves, in a general way, the degree to which they experienced wellness (Diener, 1984). In the current literature, SWB is operationally defined as, "Experiencing a high positive affect; a low level of negative affect and, certainly, a high degree of satisfaction with one's life." Subject well-being is an instance of the hedonic concept of well-being (Ryan \& Deci, 2001).

Ryff and Singer (1989) discussed and contributed to a model that measured "psychological wellbeing" (PWB). That model fell within the eudaimonic tradition and was originally drafted to challenge the prevailing hedonistic view of wellbeing within the psychological sciences. Ryff, in her thoughts, clearly acknowledges the influence of
Aristotle's view of the highest human good involving virtue and the realisation of one's potential. She also acknowledges the works of the psychodynamically and humanistically oriented psychologists such as Jung, Maslow, Allport, and Rogers (especially in the later years of the sixties) (Ryff \& Singer, 1989). Ryff's model named six characteristics of psychological wellbeing, and they are:

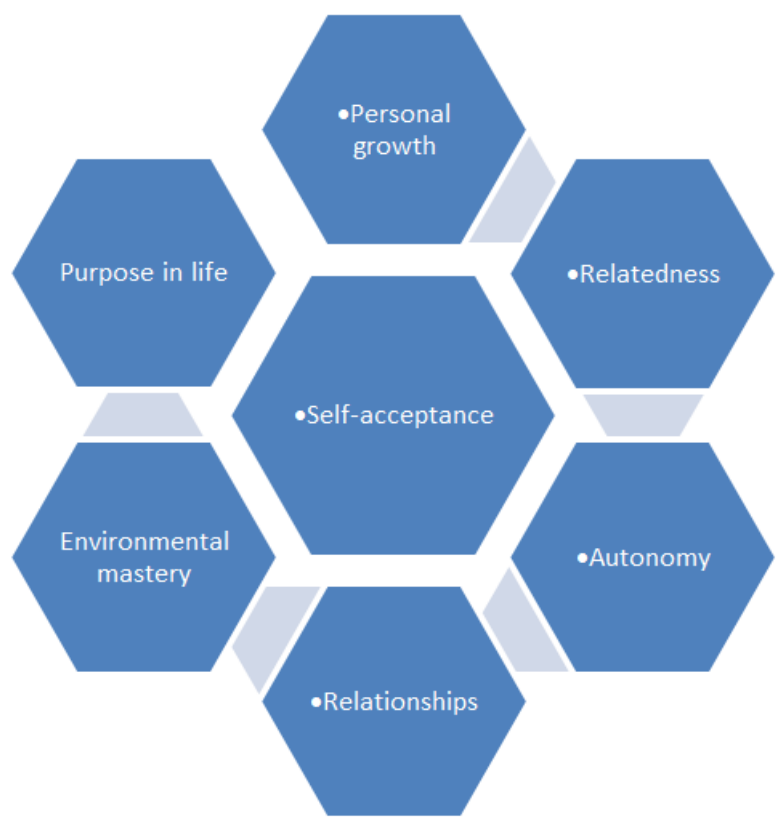

Extensive review of the studies on well-being shows that there is some element of hedonic pleasure, even in eudaimonia, and that there is far more overlap between the two models of wellbeing than was believed to be the case in the original philosophical conceptualisations. The researchers caution us thus: "We are concerned about the potential dangers of people misinterpreting a distinction between hedonic and eudaimonic happiness as meaning that there are two unrelated experiences of happiness" (Biswas-Diener, Kashdan, \& King, 2009, p. 210).

\section{Happiness and Well-being in Indian Traditions - Sukha and Änanda}

In Indian traditions, there are several terms in Sanskrit and also in other classical languages of different regions representing different shades and states of happiness and well-being. For example, Salagame (2003, p.75) has noted that the term "sukha" is generally used to represent happiness and well-being, and there are contextually specific terms which indicate the state of mind like "trpti" (satisfaction of sensual pleasures), "harsha" (excitement associated with some events), "ullassa" (feeling of pleasantness associated with the experience of natural beauty, a good breeze, etc.) and "santosha" (being pleased by some interpersonal interaction). The opposite of sukha is "dukkha," state of misery and suffering. While sukha and dukkha are the binaries that all humans experience in 
the ordinary states of wakefulness and also in dream, Indian thinkers have always sought to go beyond this pair of opposites to achieve a lasting state of well-being. It is termed "ananda" and is regarded "as the original condition of human beings and characterise Atman, the 'pure consciousness' or transcendental Self.” (Salagame, 2003, p. 74).

Keeping this in view Salagame $(2003,2006)$ has noted that in India ancient thinkers have discussed happiness and well-being in relation to both ordinary states of consciousness and transcendent states. He distinguishes them into three distinct perspectives viz., hedonistic, transcendental, and collectivist. The hedonic perspective is essentially characterized by maximizing pleasure and avoiding or minimizing pain. A group of ancient thinkers known as Charvaka upheld this position. They were materialists to the core and rejected any notions of metaphysical or mystical or spiritual. So, they looked to external things as the source of happiness and well-being. At the other end of the spectrum is the transcendent perspective which holds that happiness and well-being do not depend on any objective conditions of reality, including one's state of body-mind also. Instead, it is characteristic of our essential nature and intrinsic to self. It is to be realized within. Further, the transcendent view is an all-encompassing universal vision, which aspires to the well-being of everyone in the universe. The collectivist perspective lies between the two extremes. "The collectivist perspective takes into account the fact that there are enormous individual differences in the needs and aspirations of people." A vast majority fall in between the two extremes. "It is they who might fall into the abyss of hedonism or scale the peak of transcendence, depending on which worldview prevail upon them, material or spiritual. Keeping this vast majority in sight the Indian seer and sage established a social framework and ground rules for good life, which ensures the wellbeing of all (2003, p. 74).”

\section{Purushartha and Well-being}

Indian thinkers noted that our sense of happiness and well-being also has an intrinsic relation with the object or source from which we derive that, and it is linked to what is known as "purushartha." The term purushārtha in Sanskrit literally means "what man desires" (Purushaih arthayate iti) and it "seems to express the general tendencies, of human nature" (Hiriyanna, 1975, p. 13, footnote 28). A person may desire material wealth (artha), sensory enjoyment (kāma), virtue (dharma) or transcendence and liberation from the cycle of birth and death (moksha). So the sense of well-being is seen as linked to what an individual desires (Salagame, 2012, p, 376)." These four are regarded as goals of life and values of life. They are differentiated as "lower" and "higher" and "empirical/secular" and "spiritual values." The lower or empirical/secular values are what a man "naturally seeks," and the higher/spiritual values are what he "ought to seek." Both are termed "human values" because they are consciously sought (Hiriyanna, 1975). "Man has the potential to evolve to a higher stage. This means that a human being can strive towards perfection through the development of the virtues and strengths, which define humanness, mānava dharma. Indian thinkers went a step further and asserted that man can transcend all defining qualities to experience an identity beyond definitions, which they said is the real or true identity, known as Atman, or Self. (Salagame, 2012, 376)."

\section{Well-being Western and Indian Perspectives}

Since the publication of Well-Being: The Foundation of Hedonic Psychology (Kahneman, Diener, \& Schwarz , 1999), SWB has been associated with the hedonistic approach to wellbeing. A more precise interpretation of hedonic wellbeing would, however, use both positive affect and negative affect to index happiness because life satisfaction is not strictly a hedonic concept. Rather, it involves a cognitive evaluation of the conditions of one's life. Still, subjective wellbeing has been widely associated with the idea of happiness, and these two concepts have often been interpreted as being hedonic, although there may be room for greater integration of SWB into a more eudaimonic perspective, such as PWB. This second perspective in the western world is concerned with living well or actualising one's human potentials. This conceptualisation maintains that wellbeing is not so much an outcome or end state as it is a process of fulfilling or realising one's true nature - that is, of fulfilling one's virtuous potentials and living as one was inherently intended to live (Deci \& Ryan, 2006; Waterman, 1993).

In comparison to the current western conceptualizations, Indian ideas on happiness and well-being differ on account of the former restricting them to only those experiences of ordinary states of consciousness. The hedonic and eudaimonic distinctions are both related to the strivings of our day-to-day existence, and they do not address the possibility of a lasting state of well-being associated with transcendental state as reiterated in Indian traditions. The three values of life recognized in Indian traditions desires, wealth and virtue cover both the hedonic and eudaimonic or SWB and PWB perspectives. But it is the last one, moksha, liberation, that is not considered so far as a human possibility in the west.

\section{Discussion and Conclusions}

Since this paper focuses on how resilience, hope, optimism can be linked to the notions of well-being, 
western and Indian it is necessary to dwell a little more on resilience. When we attempted to sketch the contours of resilience, we were aware that we distinguished resilience from related concepts such as invulnerability, stress resistance, adaptive behaviours and mental toughness. Invulnerability appears to us as absolute resistance to the negative impacts of adverse situations. It has frequently been likened to resilience. However, Smith and Pryor (1995) believe that resilience is not necessarily absolute resistance, but rather recovery. This includes a wide range of responses that vary depending on the nature of the adverse circumstances. Here, it is important to differentiate between recovery after an adverse event and better skills and growth after the trauma, by defining the first response as resistance to stress and the second as resilience. (Carver, 1998; Smith, Dalen, Wiggins, Tooley, Christopher \& Bernard, 2008). So, therefore, resilience goes counter to vulnerability but covers all areas of personal competence such as emotional, cognitive and social while adaptive behaviours are necessary for facing these situations but are not enough to define resilience. Mental toughness is yet another concept that is closely related to resilience. There is an active debate on whether this mental toughness is a state of mind, a set of psychological characteristics or a predisposition to a response (Bull, Shambrook, James \& Brooks, 2005; Crust, 2007). There are a number of dimensions of mental toughness that have been identified such as: attitude (beliefs and orientations); training (long-term goals as a source of motivation, control over the environment, personal standards); competition (pressure management, conviction, self-regulation, goal maintenance, awareness and control of thoughts and emotions, context management) and; post-competition (managing failure and success) (Jones, Hanton \& Connaughton, 2007). Research by Ryff, Singer, and their colleagues has shown that higher levels of psychological wellbeing is associated with better neuroendocrine regulation, lower cardiovascular risk, and better immune functioning (Ryff \& Singer, 1989).

In the Indian traditions, there are many other terms, in addition to those already discussed, which are specifically related to our present discussion on resilience. They include ārogyam (good health), nirāmaya (freedom from disease or illness), swāsthyam (sound state of body/mind), and shubha (to shine, be splendid, and look beautiful or handsome; eminent, good, virtuous). The term ārogyam, which means "good health" (Apte, 1988, p. 85), is used to refer to both physical and mental health. The term swāsthyam is used to represent wellbeing. It has two components. "Swa" in Sanskrit means "one's own, belonging to oneself, often serving as a reflexive pronoun; innate, natural, inherent, peculiar, inborn" (Apte, 1988, p. 630;). "Stha" meaning "standing, staying, abiding, being, existing" (Apte, 1988, p. 621). The two components put together indicate a state of abiding in one's self. While the term sthitaprajna refers to this in a cognitive sense, Ayurveda defines swāsthya, as a condition of harmony in the functioning of soma, psyche, and spirit (Salagame, 2012).

Yet another word "abhyâsa" connotes several meanings, prominent are: steadiness, fortitude, endurance, resilience, discipline, regulated practice, study. Closely linked are terms such as "nishta" determination that allows one to cope with crisis; take steady steps, move in a pattern or adhere to a discipline and also be ready to surrender. With little sermonising even lay people in the Indian tradition are able to identify with pain and suffering as facts of life for all human beings, and going within therefore is an extraordinary feat for them. Possibly this is one of the best contributions to the positive psychology movement in the west. Misra $(2009$, p. 85$)$ opines that the current approach to the study of happiness and wellbeing is situated in the context of a liberal individualism that is underpinned by the notion of an "independent self" that fosters a "kind of personhood which evolves in the direction of becoming more and more individualized." For such a self, happiness and well-being imply hedonic qualities such as joy, excitement, possessions, and achievements.

Research (Pulla, 2013; Broderick, 2013, p. 254) indicates that there are connections between positive emotions "sukha", resilience and human thriving. It may appear as though views of wellbeing in the Indian tradition are all hunky dory, and connote only spiritual and may not necessarily connote material apsects, but that is not so. Though Indian seers and seekers addressed "moksha," the liberation from the cycle of birth and death as the supreme goal of human existence they were quite aware that it is not everyone's cup of tea. Indian thinkers did recognise vast individual differences among human beings. Those who aspire come in all sizes and in all shapes and hold different aspirations within their worldview. Therefore, studies or the practice of resilience "abhyâsa" had choices and strategies for provision of human refinement, thus bringing about wellbeing. But what differentiates the Indian approach from the view in the west is the latter's overemphasis on the material as against the spiritual. Ultimate good life and wellbeing lies in harmonising the two. As derivatives of the above discussions, I forward the following as concluding propositions:

a) People cope, and with each continuous crisis in life, they become stronger. This strength we name as resilience.

b) People have opportunities in their journey through resilience "abhyâsa" to look at new meaningful, contentment patterns and the values that come with resilience.

c) While coping and resilience occurs here in this material world and mostly as response to crisis crisis provides that opportunity 'to look within', which rests in the non-material domain and therefore spiritual.

"Abhyâsa" (resilience) is a spiritual practice, people's 
capacity to cope with loss, grief and insurmountable odds. In the Indian tradition - the Upanishad seem to have provided definitions of both materialistic and spiritual happiness, while in the western outlook material grief \& loss with any crisis appears to be providing an impetus for non-material consideration that there is a strong attitudinal expectation of equanimity during grief, loss, and crisis (ordinary or extraordinary) or catastrophic crisis (Nayar, 1961).

Kusum Nayar travelled across the countryside in India for a couple of years before her book 'Blossoms in the Dust' was published by Duckworth, London. In her books, she writes that she used to look at farmers in the villages as they were looking at the stars in the sky. To Nayar (1961) the farmers never seem to appear in their gaze as if they wish to hitch a wagon to the star, never seem to appear in their gaze as if they wish to pluck them, they were just admiring them for their twinkling and were possibly grateful that they remained miles away from earth.

Although not conclusive, it appears to us that happiness and wellbeing are 'sukha,' and 'santosha.', that individuals make sense as they represent their sense of wellness in the ordinary states of consciousness. This level of consciousness is associated with empirical reality and the bio-psycho-social self-sense. This probably is not the same as a state of happiness associated with spirituality or transcendence. At the same time we do note that the term sukha, would not be limited to a hedonistic view and thus its use in the sense of pleasure is generic. life and wellbeing is certainly beyond the superficial ānanda.

\section{Acknowledgements}

The first author's gratitude is expressed to inspirational conversations with Philosopher Srinivas Arka, in Mysore, December 2013.

\section{REFERENCES}

[1] Apte, V. S. (1988). The student's Sanskrit English dictionary. Delhi, India: Motilal Banarasidass.

[2] Allport, G.W. (1961). Pattern and growth in personality. New York: Holt, Rinehart, and Winston

[3] Benjamin, K. (2014). Gift. [ONLINE] Available at http://www.bcna.org.au/sharing-support/personal-stories/cr eativity-and-breast-cancer/gift

[4] Biswas-Diener, R., Kashdan, T. B., \& King, L. A. (2009). Two traditions of happiness research, not two distinct types of happiness. The Journal of Positive Psychology, 4(3), 208211.

[5] Broderick, J. (2013). Trusting one's emotional guidance builds resilience. In V. Pulla, S. Warren \& A. Shatte (Eds.),
Perspectives on coping and resilience (pp. 254-279). Laxmi Nagar, Delhi: Authors Press.

[6] Bull, S. J., Shambrook, C. J., James, W., \& Brooks, J. E. (2005), Towards an understanding of mental toughness in elite English cricketers. J Appl Sport Psychol, 17, 209-227.

[7] Carver, C. S. (1998). Resilience and thriving: Issues, models, and linkages. J Soc Issues, 54, 245-266.

[8] Crust, L. (2007). Mental toughness in sport: A review. $J$ Sport Exerc Psychol., 5, 270-290.

[9] Dalal, A. K., \& Misra, G. (2006). Psychology of health and well-being: Some emerging perspectives. Psychological Studies, 51(2\&3), 91-104.

[10] Diener, E. (1984). Subjective well-being. Psychological Bulletin, 95, 542-575.

[11] Frederic \& Brussat, M, A. (2008). Slumdog Millionaire. [ONLINE] Available at http://www.spiritualityandpractice. com/films/features.php?id=18707\#10 Most.

[12] Jones, G., Hanton, S., Connaughton, D. (2007). A framework of mental toughness in the world's best performers. Psychol Sport Exercise 21, 243-264.

[13] Jung, C. G. (1933). Modern man in search of a soul. New York: Harcourt, Brace, and World.

[14] Kahneman, D., Diener, E., \& Schwarz, N. (Eds.). (1999). Well-being: The foundations of hedonic psychology. New York: Russell Sage Foundation.

[15] Kashdan, T. B., Biswas-Diener, R., \& King, L. A. (2008). Reconsidering happiness: The costs of distinguishing between hedonics and eudaimonia. The Journal of Positive Psychology, 3(4), 219-233.

[16] Kristja'nsson, K. (2010). Positive psychology, happiness, and virtue: The troublesome conceptual issues. Review of General Psychology, 14(4), 296-310.

[17] Nair, Kusum. (1961). Blossoms in the dust : the human element in Indian development. London : Duckworth

[18] Pande, N., \& Naidu, R. K. (1992). Anāsakti and health: A study of non-attachment. Psychology and Developing Societies, 4(1), 89-104.

[19] Pulla, V. (2013). Coping and resilience: People's innovative solutions. International Journal of Innovation, Creativity, and Change, 1(1).

[20] Rutter, M. (2007). Resilience, competence, and coping. Child Abuse Neglect, 31, 205-209.

[21] Ryan, R., \& Deci, E. (2001). On happiness and human potentials: a review of research on hedonic and eudaimonic well-being. Annual Review of Psychology, 52, 141-166.

[22] Ryff, C. D. (1989). 'Happiness is everything, or is it? Explorations on the meaning of psychological well-being'. Journal of Personality and Social Psychology 57, 10691081.

[23] Salagame, K. K. K. (2003). An Indian conception of well-being. In Henry, J. (Ed) European Positive Psychology Proceedings 2002. Leicester, UK: British Psychological Society. (pp. 72-79).

[24] Salagame, K. K. K. (2006). The role of spirituality in 
attaining wellbeing: Approach of Santhana dharma. In A. D. Fave (Ed.), Dimensions of well-being In Indian tradition, Psychological Studies, 51(4), 105-112.

[25] Salagame, K. K. K. (2012). Well-being from the perspective of Hindu/Sanatana dharma. In S. David, I. Boniwal, \& A. C. Ayers (Eds.), The Oxford Handbook of Happiness. Oxford, UK: Oxford University Press. (pp. 371-383).

[26] Shelly. (2014). The courage to fly on the trapeze. [ONLINE] Available at http://www.bcna.org.au/sharing-support/perso nal-stories/creativity-and-breast-cancer/courage-fly.
[27] Smith, J., \& Prior, M. (1995), Temperament and stress resilience in school- age children: A within-families study. $J$ Am Acad Child Adolesc Psychiatry, 34, 168-179.

[28] Smith, B. W., Dalen, J., Wiggins, K., Tooley, E., Christophe,R, P., \& Bernard, J. (2008) The brief resilience scale: Assessing the ability to bounce back. Int J Behav Med., 15,194-200.

[29] Waterman, A. S. (1993). 'Two conceptions of happiness: Contrasts of personal expressiveness (eudaemonia) and hedonic enjoyment.' Journal of Personality and Social Psychology, 64, 678-691. 